\title{
THE COMMUNICATIVE ACTION TO HABERMAS: THE NECESSARY ADOPTION OF THE THEORY BY THE UN SECURITY COUNCIL
}

\section{O AGIR COMUNICATIVO PARA HABERMAS: A NECESSÁRIA ADOÇÃO DA TEORIA PELO CONSELHO DE SEGURANÇA DA ONU}

TATIANA DE A. F. R. CARDOSO SQUEFF

Permanent professor of the Postgraduate Program in Law and Adjunct Professor of International Law at the Faculty of Law 'Prof. Jacy de Assis' from the Federal University of Uberlândia - UFU. PhD in International Law from UFRGS, with a sandwich period at the University of Ottawa. Master in Law from UNISINOS, this one with CAPES scholarship and period of study at the University of Toronto, with DFAIT scholarship. Specialist in English Language from Unilasalle, in International Law from UFRGS / PPGD and in Contemporary International Relations from UFRGS / PPGEEI. Leader of the International Law Study and Research Group - UFU / CNPq.

\section{VANESSA DE O. BERNARDI BIDINOTTO}

Professor of International Law at Faculdade São Francisco de Assis (UNIFIN). Master in Public Law (UNISINOS). Post-graduated in International Relations (VERBO JURÍDICO) and in Technology and Web Innovations (SENAC). Bachelor of Laws (UniRitter). Lawyer.

\section{ABSTRACT}

Objective: The present study has as main objective to analyze whether the theory of communicative action proposed by Jürgen Habermas should be applied to the voting procedure of the United Nations Security Council. 
Methodology: The inductive methodology used is based on research on bibliography, legislation and United Nations Resolutions, as well as in doctrine, cases and articles published in specialized journals.

Results: It was concluded that the theory proposed by Habermas identifies language as a means by which those involved in a discourse can influence one another in order to change their minds or conceive intentions that corroborate their purposes. It can be clearly said that the UN Security Council has, to a certain extent, the same objective, as its purpose is to create resolutions that have the power to guarantee international peace and security.

Contributions: This study has as contribution the theory of communicative action proposed by Habermas which is explained by way of a concrete case.

Keywords: Communicative action; living world; Security Council; veto power; United States of America.

\section{RESUMO}

Objetivo: O presente estudo tem como objetivo central analisar se a teoria do agir comunicativo proposta por Jürgen Habermas, deveria ser aplicada às normas de votação do Conselho de Segurança das Nações Unidas.

Metodologia: A metodologia indutiva utilizada é baseada em pesquisas bibliográficas, legislativas e de resoluções das Nações Unidas, bem como em doutrina, casos e artigos publicados em periódicos especializados.

Resultados: Concluiu-se que a adoção da teoria da ação comunicativa seria importante para alcançar os objetivos da Organização, a saber, paz e segurança global. A teoria proposta por Habermas identifica a linguagem como um meio pelo qual os envolvidos em um discurso podem influenciar-se mutuamente, a fim de mudar de ideia ou conceber intenções que corroborem seus propósitos. Diante disso, pode-se dizer claramente que o Conselho de Segurança da ONU tem, em certa medida, o mesmo objetivo, pois seu objetivo é criar resoluções que tenham o poder de garantir a paz e a segurança internacionais.

Contribuições: Este estudo tem como contribuição a teoria da ação comunicativa proposta por Harbemas, que é explicada por meio de um caso concreto.

Palavras-chave: Agir Comunicativo; mundo vivente; Conselho de Segurança; poder de veto; Estados Unidos da América. 


\section{INTRODUCTION}

This paper aims to analyze the theory of communicative action proposed by Habermas in order to verify if this can be applied to the Security Council of the United Nations, mainly regarding the rules of voting adopted by the body. To do so, starting from the inductive method, there are two cases where the inequality between the members of the Council has jeopardized the realization of the central objectives of the Organization itself, namely, peace and international security, more specifically, the arbitrariness of the United States by acting against Iraq and the vetoes of this country in defense of Israel in the Arab-Israeli conflict.

The central question that permeates the present study is why it would be interesting to adopt the theory of communicative action, proposed by Jürgen Habermas by the United Nations Security Council in order to solve the problem of the use of the veto exercise by the members in defense of their national interests. In order to respond to the problem proposed, after presenting the question concerning the Security Council together with the case of the Iraq War and the Conflict in the Gaza Strip, the text will be directed to the presentation of the theory proposed by the German philosopher, pointing to the need - or not - for its use within the Council. In addition, it should be pointed out that, for such purposes, a descriptive research, of an applied nature was carried out, using the bibliographic and documentary procedures, which were selected qualitatively.

\section{THE UN SECURITY COUNCIL AND THE AMERICAN UNILATERAL PERFORMANCES IN REGARD TO THE USE OF FORCE}

\subsection{THE COUNCIL OF SECURITY AND THE POWER OF VETO}

The United Nations (UN) was established in 1945 and has its headquarters established in New York, representing the main reference among international 
organizations, mainly because it has a universal character, in addition to being open for participation of all States, UN can deal with any subject that is the subject of international cooperation (PORTELA, 2012, p. 263). Although the UN was founded by only 51 member states, which signed its charter in San Francisco on June 26, 1945, the Organization now has the participation of 193 member states (LUZ, 2012).

Among the objectives of the UN, listed in the preamble and in Article 1 of the Charter of the United Nations, the main purpose of this work is to maintain peace and international security. This objective refers mainly to one of the functions of the Security Council, one of the main bodies that make up the organization (UN, 1945, art. 7). After all, the UN Security Council has the power to determine breaches of this purpose, and may direct the Organization's action in favor of its effectiveness. (GUILHERME, 1980, p. 84; MAZZUOLI, 2011, p. 624).

This body has a total of fifteen members, five of whom are permanent and ten are rotated among the other members of the Organization for two-year terms (UN, 1945, art. 23). The permanent members were established by art. 23 of the Charter, and are China, France, Russia (which remained in place of the Union of Soviet Socialist Republics - USSR), the United Kingdom and the United States of America.

The other 10 members are elected by the General Assembly, taking into account the contribution to peacekeeping, international security, other purposes of the UN and the geographical distribution established by Resolution 1991-A (XVIII) (UN, 1963). The resolution states that five countries should be from Africa and Asia, one from Eastern Europe, two from Latin America and two from Western Europe and other states.

In voting sessions, each member of the Security Council shall have one vote. For the adoption of a resolution, nine affirmative votes are required, regardless of their quality - whether permanent or rotating. Therefore, even if a "crude" reading of the UN Charter refers to the need for affirmative votes of all permanent members 
(UN, 1945, art. 23), it should be noted that they can also abstain from voting ${ }^{1}$, so that it is not necessarily necessary that they approve the measure for it to be adopted ${ }^{2}$.

In other words, it is enough to obtain nine affirmative votes, regardless of the possible abstention of any permanent member (or all). However, the existence of vetoes of permanent members imply, rather, their "disapproval." This stems from the possibility that a permanent member may veto Security Council resolutions in order to avoid approval of the project under consideration. It should be noted that it is not necessary for all countries that permanently occupy seats in the Council to veto the project, only one vote of this type of member being necessary for their rejection.

Moreover, there is no need to justify the veto. It is precisely in this respect that the problem remains, since the use of the veto is not always based on an international interest. At some moments in the history of the UN, the veto has been used in the light of national interests, mainly by the United States of America, as will be discussed below.

\footnotetext{
1 This situation remained very evident when the then USSR occupied the seat in the Council, as summarizes Andrew J. Carswell: "The Soviets then boycotted the Council in January 1950 to protest the occupation of the Chinese seat by its government-in-exile rather than communist Peking. When North Korean troops crossed the 38th parallel into the newly recognized Republic of Korea in June of that same year, a small window opened for the Security Council. It passed resolution 82 on 25 June 1950 by nine uncontested votes (Yugoslavia abstained and the Soviets were absent from the 11 member body), determining pursuant to article 39 of the UN Charter that North Korea's attack represented a breach of the peace and opening the door to measures under articles 41 and 42 . The second resolution (83) passed on 27 June by seven votes to one with two abstentions (the Soviets remained absent). It recommended 'that the Members of the United Nations furnish such assistance to the Republic of Korea as may be necessary to repel the armed attack and restore international peace and security in that area"' (CARSWELL, 2013, p. 457).

2 This is what David Schweigman summirizes from the interpretation of the International Court of Justice: In the advisory opinion on the legal consequences of the continued presence of south africa in namibia (south west africa) notwhistanding security council resolution 276 (1970), the Court pronounced itself on South Africa's contention that the resolution by which teh Council requested the opinion, resolution 284 (9170), was invalid due to the abstention of two permanent members. The Court held that: 'the proceedings of the Security Council extending over a long period supply abundant evidence that presidental rulings and the postions taken by members of the Council, in particular its permanent mebers, have consistently and uniformly interpreted the practice of coluntary abstention by a permanent meber as not contitutinf a bar to the adoption of resolutions.... This procedure followed by the Security Council, which has continued unchanged after the amendment in 1965 of Article 27 of the charter, has been generally accepted by the Members of the UNited Nations and evidences a general practice of the Organization.' (ICJ Rep [197], at. 22) (SCHWEIGMAN, 2001, p. 48 - footnote 203).
} 


\subsection{THE WAR OF IRAQ AND THE CONFLICT IN THE GAZA STRIP: EXAMPLES OF USA'S UNAUTHORIZED ACTION}

One of the most important examples and one of the greatest international repercussions on the United States' disregard for the UN Security Council and its prerogative to authorize the use of force was the Iraq War. From the point of view of the United Nations, the aforementioned conflict was totally illegal, subversive and prejudicial to the development of international law.

The United States has presented seven official arguments to justify the war against Iraq, namely: (1) that Baghdad would not have respected $16 \mathrm{UN}$ resolutions; (2) that Iraq would or would have weapons of mass destruction; (3) which would be guilty of human rights violations (torture, rape, summary executions), (4) terrorism (Baghdad would be covering Palestinian organizations and sending money to every perpetrator), (5) which would keep prisoners of war (including a US pilot), (6) who had confiscated goods during the invasion of Kuwait (works of art and military equipment), and (7) the mismanagement of goods for the "oil-for-food" program (RAMONET, 2003).

In light of the serious allegations against Iraq by the United States, the Security Council unanimously adopted Resolution 1441 on November 8, 2002. That resolution established an inspection regime, whereby Iraq should submit within 30 days a list of all chemical, biological and nuclear weapons programs that the country possessed, in addition to the long-range missiles (UN, 2002).

At no point, however, did the resolution authorize the US to use military force against the country. This was a negotiated resolution in order for Iraq to cooperate with the United Nations Monitoring, Inspection and Monitoring Commission (UNMIMC), which had the objective of verifying that Iraq would comply with its obligation to dispose of its weapons of mass destruction. mass destruction and operate a system so that the country would not re-acquire the same weapons (UNMIMC, s/d). 
Nor has Iraq complied with the resolution, so that the country could suffer "grave consequences", according to the document itself. On March 7, 2003, the United States, United Kingdom and Spain proposed to the Security Council a resolution to disarm Iraq, demanding that the country so act until March 17, 2003, otherwise it would suffer an armed attack under art. 42 of the UN Charter (i.e., the exception to use of force when authorized by the Council). Explicitly, on March 10, France and Russia said they would veto such proposal (FOLHA ONLINE, 2003).

Without support, and knowing that the resolution would be overturned by the veto of two permanent Security Council countries (France and Russia), the US gave up submitting the proposal. However, on March 20, 2003, contrary to the UN and the ius ad bellum rules which prohibit the use of force at the international level, then US President George W. Bush ordered the invasion of Iraq in a war that would last more than a decade and would cost the lives of more than 115,500 Iraqi civilians and 4,483 US military personnel (SACONI; ENTINI, 2013).

This case demonstrates the disrespect of the United States to the UN and to international law itself, since the use of force is forbidden in art. 2(4) of the Charter of the Organization (UN, 1945) and is considered to be a cogent rule ${ }^{3}$. It would only be the same authorized with the proper consent of the Council, as mentioned above, under the terms of art. 42 or in self-defense, under the terms of art. 51 of the Charter (UN, 1945).

In that sense, after failing to obtain the aforementioned "go" from the Council, the States attempted to base its decision of invasion on the basis of legitimate defense, in spite of a new argument, of preventive self-defense ${ }^{4}$, since there had been no previous effective action or imminent attack on the part of Iraq that would lead to a legitimized counter-attack by the US, and what was then rejected by

\footnotetext{
3 "The principle of the non-use of force belongs to the realm of jus cogens, and is the very cornerstone of the human effort to promote peace in a world torn by strife" (ICJ, 1986, p. 156).

4 "The Bush Doctrine of anticipatory self-defense, or preventive war [...] [is triggered when] there is reasonable justification to be concerned and to take remedial steps to ensure that the situation [that poses a threat, not particularly imminent] is reversed" (COHAN, 2003, p. 290); "The US [...] seeks to argue that circunstances have changed and that the requirement of imminent attack should be rethought in order 'to adapt it to the capabilities and objectives of today's adversaries'. The new doctrine goes far beyond the previous rare claims to preemptive action" (GRAY, 2002, p. 442).
} 
international society 5 . Therefore, the attitude of the United States in Iraq was considered contrary to the norms of international law and to the Organization itself.

This American attitude can also be noted in US vetoes on behalf of the State of Israel, since the US has vetoed more than 35 draft resolutions against Israel. These include the US veto to the Palestinian proposal put forward in December 2014 to put an end to the Gaza conflict, leading to an end to peace negotiations and occupation of their territories (BATICHE, 2014).

The "new" Gaza conflict began in the twentieth century and was fueled by the anti-Semitism suffered by Jews in Europe. During World War II, the British, who made several promises to the Arabs, excluding the Jewish people, received a League of Nations mandate to administer the Palestinian territory (BBC BRASIL, 2014).

This split between the peoples resulted in a climate of great tension between Arabs and Jews that ended in clashes between the Jewish and Arab paramilitary groups. After the Second War and the Holocaust, there was an increase in pressure for the establishment of a Jewish state, with the original plan providing for the sharing of territory controlled by the United Kingdom (BBC BRASIL, 2014).

After the founding of Israel in 1947 by the General Assembly through Resolution 181 (II) (UN, 1947), tension ceased to be local to become a regional issue, and the next day it was invaded by Egypt, Jordan, Syria and Iraq. The first Arab-Israeli war, known by the Jews as the war of independence or liberation, was glimpsed there. After the war, the territory originally planned by the UN for an Arab state was halved.

For the Palestinians, it was at that moment that the catastrophe began, causing 750,000 Palestinians to flee to neighboring countries or be expelled by Israeli troops. Another battle that completely changed the scenario of the region was the Six Day War in 1967, which represented a victory for Israel against an Arab coalition, resulting in occupation of the Gaza Strip, the Sinai Peninsula, the West

\footnotetext{
5 "[M]ost UN members have rejected the Bush doctrine as inconsistent with the traditional view that armed force can be only used when authorized by the security council or in self-defense" (GARDNER, 2003, p. 585).
} 
Bank, Jordan, the Golan Heights and Syria, and whose violence was terminated with the unanimous approval of Security Council Resolution 242 (UN, 1967), although it was issued under the auspices of Chapter VI of the UN Charter and, only a recommendation to the parties - in spite of some success.

In 1973 Israel and its neighbors faced up again violence, putting Egypt and Syria against Israel in an attempt by the Arabs to reclaim the territories lost in 1967 and then occupied by the Israelis. The cease-fire of this new wave of violence occurred through Resolution 338 of the Security Council (UN, 1973), which called for peace in the region under the terms of Resolution 242 of 1967. And due to the American participation ${ }^{6}$, Egypt came to peace with Israel, who vacated the Sinai Peninsula in 1979, and Jordan reached a peace agreement in 1994 (BBC BRASIL, 2014).

In 2014, following a collapse of United States-sponsored peace talks since the 1990s, which had as high points the Oslo Agreement in 1993, when there was mutual recognition between Israel and the Palestine Liberation Organization - PLO (RUODEN, 2015), and the Camp David Summit in 2000, when an agreement between Ehud Barak and Yasir Arafat came to be tackled (NYT, 2000), and the announcement of a non-national government between Fatah and Hamas, the Palestinian political arms, a new intifada has begun, particularly since the kidnapping three young Israelis who were found dead in the West Bank, for which Israel blamed Hamas and arrested hundreds of members of the group, restarting the conflict (BBC BRASIL, 2014).

In order for Israel to have peace, Israel would have to accept the creation of a sovereign state for the Palestinians, an end to the blockade of the Gaza Strip and an end to restrictions on the movement of people and goods in the West Bank, East

\footnotetext{
${ }^{6}$ These are the Camp David Accords: "The first was called A Framework for Peace in the Middle East. It laid down principles for peace, expanding on resolution 242, set out what it hoped was a way of resolving what it called the "Palestinian problem", agreed that there should be a treaty between Egypt and Israel and called for other treaties between Israel and its neighbours"; and "The second accord was the The Camp David framework for the peace treaty between Egypt and Israel. This followed in 1979, after an Israeli withdrawal from the Sinai. This was the first recognition of Israel as a state by a major Arab country. The talks probably stand as the most successful negotiations in the whole peace process" (BBC NEWS, 2013).
} 
Jerusalem and the Gaza Strip and Palestinian groups should renounce violence and recognize the State of Israel (BBC BRASIL, 2014). The resolution proposed by Palestine to the Security Council in 2014 granted a deadline of 12 months for the conclusion of negotiations for an agreement and appealed to Israel to withdraw consolidation of the Palestinian state and Israel would share Jerusalem as capital, just as the General Assembly in 1947 when he had created the State of Israel by the aforementioned Resolution 181 (LUSA, 2014).

Moreover, this resolution proposed by Palestine received 8 votes in favor, 2 votes against and 5 abstentions. The US and Australia, allies of Israel, voted against the proposal. In the face of the US veto, the proposal could not be adopted, even if it had a total of 9 votes in favor, since the United States is a permanent member, and all Security Council decisions can not contain the refusal of permanent your approval (BATICHE, 2014). To a certain extent, all resolutions aimed at attracting responsibility to the State of Israel, ${ }^{7}$ such as for settlements in the territories occupied in 1967, or Palestine's own membership of the UN as a Member-State (MCGREAL, 2011), receive the same negative response on the part of from the USA.

This example of the Arab-Israeli conflict, alongside the Iraq War, demonstrates that the rule for voting on resolutions by the Security Council leaves approval or not of a motion for resolution to the permanent members. And, it can be considered that these five countries, often as the two examples considered, take into account their national interests to decide on a proposed subject.

This is not only a principle of public international law, but also the UN Charter, which establishes, in art. 2, the principle of equality of all Member-States as one of the main principles of the Organization. In this sense, it is possible to see the need to adopt the theory of communicative action proposed by Jürgen Habermas for the UN to change its norms, particularly in the Security Council as it is the place where the use of force is debated, in order to comply with the abovementioned principle of equality.

\footnotetext{
7 The US tends to veto the resolutions in the UN Security Council, with the exception of the last meeting during the Obama administration, in which the US surprisingly abstained. See PILKINGTON, 2011; and CORTELESSA, 2016.
} 


\title{
3 THE NECESSARY APPLICATION OF THE THEORY OF COMMUNICATIVE ACTION WITHIN THE SECURITY COUNCIL
}

\subsection{HABERMAS' THEORY OF COMMUNICATIVE ACTION}

The concept of communicative action, for Habermas, consists in a linguistic medium in which the relations of the actor of the world are reflected as such. Once this level of concept formation has been achieved, the problematic of rationality, which up to now has led to the social scientist, now falls within the perspective of the agent himself (HABERMAS, 1987a, p. 136).

In fact, what Habermas intended was to replace the old practical reason, proposed by Kant, for a communicative reason that would be free of the solipsist subject, in this sense stresses Streck (2011, p. 98):

\begin{abstract}
In reality, it is not a matter of Habermas to replace practical reason; what is happening is that practical reason is called communicative action (now free of the solipsist subject, according to the German philosopher), simply to accentuate the interactive, dialogical side of all decisions that result from practical reason. Hence, Habermas intends to overcome practical reason in the solipsist, representational or conscientialist sense, through a communicative reason, but which at this point is not without practice, because now it is moved to another place: the previous foundation of the acts of the practical world. ${ }^{8}$ (Our translation.)
\end{abstract}

It is important to emphasize that Habermas distinguishes two forms of communication: ordinary communicative action and discourse. While ordinary communicative action presupposes the validity of meaning connections for the exchange of information, discourse represents something critical, that is, it

\footnotetext{
${ }^{8}$ Original text in Portuguese: "Em realidade, não se trata, em Habermas, de substituir a razão prática; o que ocorre é que a razão prática passa a se chamar de agir comunicativo (agora livre do sujeito solipsista, segundo o jusfilósofo alemão), simplesmente para acentuar o lado interativo, dialogal de todas as decisões que resultam da razão prática. Então, Habermas pretende superar a razão prática no sentido solipsista, representacional ou consciencialista, através de uma razão comunicativa, mas que, neste ponto, não deixa de ser prática, porque agora deslocada para outro lugar: a fundamentação prévia dos atos do mundo prático".
} 
represents the problematization of validity claims, without the exchange of information (OLIVEIRA, 2001, p. 303-304).

Habermas made a first attempt at articulation, which he called the "theory of communicative competence," in which elements of modern transcendental philosophy and elements coming from linguistics and the philosophy of language are mediated in order to ground the starting point of a "theory critical of society" (OLIVEIRA, 2001, p. 293). He made his theory in analogy with Chomsky's theory of linguistic competence, which is considered partial to Habermas, since he does not take into account the fact that "universal structures of possible linguistic situations, themselves produced by linguistic acts" (OLIVEIRA, 2001, p. 294).

Chomsky differentiates, in his theory, the linguistic competence of his performance. Competence could be said to represent the "capacity of an ideal speaker to master an abstract system of generative rules of language," as a consequence of which the ideal speaker would always actualize this competence within limiting constraints (OLIVEIRA, 2001, p. 294). Therefore, the concrete language could be explained from two fundamental constituents: the competence and the conditions limiting the application of this competence. However, it is recalled that this differentiation is partially accepted by Habermas.

The language for Habermas cannot be explained by the competition of competence and concrete conditions, it is necessary to thematize a third dimension that makes it possible to situate the other two, as Oliveira (2001, p. 294-295) explains:

To distinguish clearly, the linguistically dependent structures of the speech situations of the linguistic expressions that are employed in these situations, Habermas distinguishes sentences and utterances. Sentences represent linguistic units that consist of linguistic expressions, while utterances are situated sentences, that is, they are pragmatic units of speech. ${ }^{9}$ (Our translation.)

9 Original text in Portuguese: "Para distinguir com clareza, as estruturas, linguisticamente dependentes, das situações de fala das expressões linguísticas que são empregadas nessas situações, Habermas distingue sentenças e proferimentos. As sentenças representam unidades linguísticas que constam de expressões linguísticas, enquanto os proferimentos são sentenças situadas, ou seja, são unidades pragmáticas de fala". 
The task of this proposed theory is the reconstruction of the system of rules, through which a possible speech situation is produced or generated. In other words, the purpose is to explain the work done by the speaker and the listener with the aid of the pragmatic universals.

The specific purpose of universal pragmatics as a theory of communicative competence lies in "rebuilding the system of rules from which a speaker, communicatively competent, constructs utterances from sentences and transforms utterances into other utterances (OLIVEIRA, 2001, p. 299). Therefore, pragmatics is used to reconstruct the system that a competent speaker has to master in order to fulfill this postulate, so it can be said that this system represents a requirement of consensus (DUTRA, 2005, p. 48).

Action devises language as a medium through which speakers, guided by their own success, can influence one another in order to change their minds or conceive the intentions that suit them for their purposes (HABERMAS, 1987a, p. 137). Hence, it is possible to say that universal pragmatics reconstructs communicative competence.

The theory of Habermasproposes language as a means of understanding in which the speaker and the listener refer, from a pre-interpreted horizon which is the world of life, simultaneously representing something that is present in the objective world, in the social world and in the subjective world (HABERMAS, 1987a, p. 136137; HABERMAS, 1987b, p. 171). It aims to identify and reconstruct the universal conditions of possible understanding (DUTRA, 2005, p. 41-42).

It is important to note that understanding is achieved only when at least two subjects attain at the same time two levels: that of intersubjectivity, in which the listener and the speaker speak to each other, and the level of objects, over which they understand each other (OLIVEIRA, 2001, p. 297). However, for an understanding to be realized, Habermas provides a catalog of word classes that relate to the structures of the speech situation. 
These expressions referred to by Habermas are called pragmatic universals because they coordinate with the universal structures of the speech situation. They are: personal pronouns, words and phrases that are used to open a speech and those used in the treatment of people, indicative expressions, performative verbs and intentional verbs.

Habermas understands an act of speech when we know what makes it acceptable, which makes it subjectively valid (DUTRA, 2005, p. 56). It is said that the communication of language is structured in "double dimensionality", since it is an association of a speech act and a sentence of propositional content. In other words, a speech act is composed of a performative sentence and a sentence of propositional content depending on the first.

Moreover, one can only use sentences in utterances when we produce the conditions of possible communication, and with it, the speech situation itself with the aid of pragmatic universals, that is:

(...) the dimension of intersubjectivity in which people establish dialogic relationships and thus can emerge as subjects capable of speaking and acting, and the dimension of objects, in which there is a reproduction of reality as the object of possible declarative sentences (OLIVEIRA, 2001, p. 301). ${ }^{10}$ (Our translation.)

The two-dimensionality of the language situation is more easily perceived and the two dimensions are located: the dimension of intersubjectivity and the dimension of objects.

Based on Searle's essential rule, speech acts are separated into four classes: (1) the communicative ones, which serve to express the meaning of the conversation, (2) the verbal ones, which express the meaning of cognitive use of the sentences, (3) the representatives, which serve to express the pragmatic sense of the self-representation of a speaker to a listener, and, (4) the regulatives, which express the performance of institutionally ruled actions (OLIVEIRA, 2001, p. 302).

${ }^{10}$ Original text in Portuguese: "(...) a dimensão da intersubjetividade na qual as pessoas estabelecem relações dialogais e, assim, podem emergir como sujeitos capazes de falar e agir, e a dimensão dos objetos, na qual há uma reprodução de realidade como objeto de possíveis sentenças declarativas". 
A speech act has a double structure, the first part, the illocutionary, is performed with the help of a performative sentence, and the second part, the propositional component, which is formed with a sentence of propositional content (HABERMAS, 1997, p. 335). The first part fixes the pragmatic sense, that is, the pretension of validity required, while the second part fixes what it is spoken.

Habermas says that this dual structure of the speech acts of reflexivity inherent in language, since in any act of speech, the participants in a dialogue must communicate on both levels: in the illocutionary and non-propositional (HABERMAS, 1997 , p. 335). For Habermas, the theory of speech acts has the purpose "to clarify the performative character of the emissions, the character that is equal to the illocutionary force of an act of speech, is to fix the mode of the emitted content" (HABERMAS, 1997, p. 332).

The aim of discourse, of communication, is to reach a true consensus, and for this, Habermas supposes an "ideal linguistic situation", or, also considered, an ideal situation of speech. The consensus can only be legitimized through an ideal situation of speech that is based as a normative basis of the linguistic understanding, being it anticipated and effective (OLIVEIRA, 2001, p. 314).

It may be said that (1) all speech has meaning only if at least two subjects act on each other or agree on something, (2) understanding means the production of a true consensus, and (3) the distinction between what is a true consensus is a false is only possible when it refers to an ideal linguistic situation. Therefore, this idealization of speech is an anticipation that we should make in any conversation with which we want to make a speech (OLIVEIRA, 2001, p. 317).

The ideal linguistic situation excludes the systematic corruption of communication, that is, it represents the equal distribution of chances for interpretations, affirmations, clarifications, justifications, etc. It represents the realization of the universal and unavoidable presuppositions that constitute the communicative rationality (DUTRA, 2005, p. 85-86), therefore, Habermas (1990, p. 181) characterizes the communicative reason as a "oscillating shell". 
Two misunderstandings must be removed, namely: (1) the conditions of empirical speech are not the same as those of the ideal speech situation, and (2) the fundamental norms of all possible conversation, as explained by universal pragmatics, are only "Practical hypotheses", through which the critical theory of society is elaborated. On the ideal linguistic situation, Oliveira (2001, p. 319) refers that:

\begin{abstract}
But it is the structure of the possible speech that we, in the performance of speech acts, counterfactually act so that the ideal linguistic situation is not pure fiction, but real, and this is what Habermas calls a presupposition. This formal anticipation of the idealized conversation guarantees the definitive and counter-factual agreement that should bind, a priori, speakers / listeners. However, this situation is not an existing situation, because no factual situation adapts to it. [...] This anticipation has for each possible communication the form of a constitutive illusion which, at the same time, is a previous manifestation of a way of life..$^{11}$ (Our translation.)
\end{abstract}

The ideal situation of speech allows the use of speech acts at all levels of a theoretical discourse, aiming to extrapolate the constraints present in the communication structure, thus allowing the questioning of several levels of theoretical discourse. The first level is guided by a pretension of validity not put to the test (theoretical discourse), the second is one that forms a theoretical foundation to problematize the certainties present in the first level (HABERMAS, 1990, p. 153).

The third level presents the possibility of revising the reasoning brought by the second level, already in the fourth level, it is reflected on a change of the systems of languages of foundation. In this last level of the theoretical discourse one is beyond the discourse and tries to determine what the question of what should be worth as knowledge (HABERMAS, 1990, p. 153).

The ideal linguistic situation is constituted by the principle of discourse that represents the consensual resolution of pretensions of validity, however, in this bias, 11 Original text in Portuguese: "Pertence, porém, a estrutura da possível fala que nós, na execução
dos atos de fala, contrafatualmente ajamos para que a situação linguística ideal não seja pura ficção,
mas real, e isso é o que Habermas chama uma pressuposição. Essa antecipação formal da conversa
idealizada garante o acordo definitivo e contrafatual que deve ligar, a priori, falantes/ouvintes.
Contudo, essa situação não é uma situação existente, pois nenhuma situação fática se adapta a ela.
[...] Essa antecipação tem para cada comunicação possível a forma de uma ilusão constitutiva que,
ao mesmo tempo, é uma manifestação prévia de uma forma de vida". 
the truth abandons its content characteristic and happens to be a truth as necessary idealization, since it is argumentative, being reached through consensus (STRECK, 2011 , p. 97). Discourse presupposes the equal participation of all those involved in a discussion, and who are motivated, solely, by the search for the best argument (DUTRA, 2005, p. 90).

Therefore, only the consensus obtained in this ideal situation is that it could be considered rational and, consequently, be considered as a criterion of truth. Therefore, it can be said that consensus is a kind of regulatory ideal which must always be sought by the participants in a communication (HABERMAS, 1997, p. 153).

The ideal linguistic situation represents the idea that the pretensions of validity, which constitute the acts of speech, are performed through discourse. This happens because the discourse presupposes the symmetrical participation of all those involved in a communication, being exempt of any type of coercion.

The difficulty of communicative action lies in dissent, which has its chances increased proportionately with the complexity of contemporary life. Dissent can be defined as the unproductive communicational form, that is, that there is no possibility of an effective social, integrated or harmonious production (SITO, 2012, p. 89).

In the theory of communicative action, performative self-contradiction must be avoided in order to arrive at a minimum notion of validity. In other words, arguments that can be seen as the principle of ultimate foundation, those that can not be challenged without performative self-contradiction, and which, because of this can not be logically grounded without a circle, should be avoided (DUTRA, 2005, p. 12).

The petitio principii must be avoided in order to reach a consensus, the existence of the petitio principii is perceived at the moment when it is denoted an argument that 'raises the question', an argument that uses the conclusion that intends to arrive as one of the premises. However, it is also said that argumentation in circles, that which is characterized when one pleads an argument with another, is also considered a petitio principii (MATILAL, 2008, p. 46) 
In order for dissent to be removed, congruent and convergent lines of action are required, since disjunctive attitudes of participants can bring chaos to habermasian systematics. Therefore, communicative action presupposes that subjects proceed with the aim of reciprocal understanding, before any separation (SITO, 2012, p. 89). Thus, it can be concluded that the ideal speech situation is a condition of the possibility of any understanding, since it is inseparable from the structure of speech itself; however, it is a counterfactual assumption, since it is never fully effective in the concrete conditions (DUTRA, 2005, p. 91).

The goal of Habermasl with the idea of communicative action is to demarcate another idea of rationality that is capable of producing normative agreements. Communicative action has a kind of mainstay that would be constituted by a background knowledge and this is the knowledge that sustains the interpretations of the participants of a particular communication, which, as will be seen in the sequence, is called as lived world (ZANELLA, 2009, p. 700).

\subsection{THE QUESTION OF THE LIVING WORLD IN HABERMAS AND THE CRITICISM TO THE SECURITY COUNCIL}

The concept of the world of life is a concept that complements communicative action, since this analysis aims to identify structures that, in front of the historical inventions of the worlds of life and particular life forms, are presented as variants (HABERMAS, 1987b, p. 169-170). Habermas' proposal consists in the link between his "theory of speech acts" and the concept of "lived world" work for hermeneutics.

Habermas (1987b, p. 170) considers society, simultaneously, as a system and as a world of life, so it can be said that the lived world is the background of communicative action, it is culture, customs, language, that is what it provides the dialogue between two or more people is what, in a way, generates the arguments that will be used. 
It is the horizon in which one lives, it is in him that the agents fix their pretensions of truth, not constituting only by cultural convictions, but also by the institutional order and structures of the personality. In Habermas' theory there is the world of life composed of social groups, where actions are coordinated by understanding, and there is the world of systems that self-regulates through actions towards certain ends (ZANELLA, 2009, p. 700).

One can see that the lived world represents the process of understanding between different people from a common background about something in the world of facts, in the social world of norms and in the subjective world of experiences (OLIVEIRA, 2001, p. 334). That is, a subject may relate to something that takes place, or can be produced in the objective world, with something that is recognized as due in a social world shared by a collectivity, or something that other actors attribute to the subjective world of the speaker, to which he has privileged access (HABERMAS, 1987b, p. 170).

Therefore, the lived world is a condition of possibility of the communicative process, representing a reservoir of unstated evidences and convictions, constituting the intersubjectively shared sense through which people can communicate. Streck (2011, p. 94-95) further emphasizes that Habermas' choice for the concept of the lived world:

[...] in addition to being made from the field of Husserl's transcendental phenomenology - hence the philosophy of consciousness - and besides being a choice of a foundation for a representational theory, is a concept converted by Habermas into a discourse only pragmatic-empirical. ${ }^{12}$ (Our translation.)

The lived world is where the communicative rationality is processed, being able to be seen as a horizon of cultural and linguistic evidences (DUTRA, 2005, p. 97). It not only forms an environment conducive to mutual understanding, but also

12 Original text in Portuguese: "[...] além de ser feita a partir do campo da fenomenologia transcendental de Husserl - portanto, da filosofia da consciência - e além de ser uma escolha de um fundamento de uma teoria representacional, é um conceito convertido por Habermas em um discurso apenas pragmático-empírico". 
provides the resources necessary to achieve it, it offers an abundance of cultural truisms from which the speakers withdraw their "effort to interpret the agreed-upon exegesis models" (HABERMAS, 2013, p. 166).

There is already a cultural deposit of the convictions of a community, and this prior knowledge provides the agents with a prior interpretation of the possible relations between the formal world concepts: the objective world, the social and the subjective world (OLIVEIRA, 2001, p. 335-336). Thus, the lived world represents an a priori of meaning that is constituted in the process of social interaction, that is, in that process related to the forms of intersubjective understanding - language -, thus representing the universal condition of any linguistically mediated communication.

Habermas (1987b, p. 176) abandons the categories of philosophy of consciousness in which Husserl addresses the problematic of the lived world, to represent it as a "collection of culturally transmitted and linguistically organized patterns of interpretation." In other words, language and culture are elements that constitute the world of life, and it can be said that the lived world is communicatively structured.

It is the structures of the life-world that fix the forms of intersubjectivity of the possible understanding, to which the participants in a communication can be understood. The lived world is, so to speak, the transcendental place where the speaker and listener meet, where both can interact reciprocally, and who can criticize and expose the fundamentals of their validity claims, resolve their differences, and come to an agreement (HABERMAS, 1987b, p. 179).

Habermas (1987b, p. 187) sees the lived world as a horizon where the concrete resolution of the claims of validity takes place, and this certainty is due to "a social a prior inscribed in the intersubjectivity of the linguistic understanding." However, the limits of the lived world are seen as something insurmountable, since it is not something petrified in time and unalterable.

It can be said, conversely, that the certainties of the lived world are almost infallible, since the lived world, besides representing a substratum of unquestionable certainties, is essentially constituted by a communicative process that is directed 
towards the understanding (DUTRA, 2005, p. 82). Therefore, the certainties of the lived world can be a matter of discussion if they become problematic (HABERMAS, 1987b, p. 568).

For this reason, at some point, what has always been beyond doubt, can become problematic, as if the world were coming down, putting an end to all the certainties (HABERMAS, 1987b, p. 568). And, to a certain extent, this is how the lived world must reproduce, otherwise we would be faced with a world lived petrified in time (DUTRA, 2005, p. 83-84).

This static connotation of the lived world would not agree with the concept of communicative rationality, which constitutes the lived world, and, therefore, Habermas adopts the thesis that the lived world is constituted of certainties insurmountable for us, but that little by little, may come down. In order to demonstrate the breakdown of certainties in the world, Habermas (1987b, p. 568) makes an analogy of philosophy with an earthquake:

\footnotetext{
Only an earthquake makes us aware that we had considered the soil that we are and move on a daily basis unmoved. But even in such situations, only a small fragment of background knowledge becomes uncertain, it is torn from its inclusion in complex traditions, in solidary relationships and in individual competences. ${ }^{13}$ (Our translation.)
}

The human being thinks that the place where he lives is, and always was the same way, and that there is no way to change, until the moment when an earthquake occurs, devastating that which existed and destroying the human certainty of things. In the same way the world of life works, since it is not petrified and, although it has certainties, these can be doubted at any moment.

Streck understands (2011, p. 94), however, that the concept of the lived world chosen by Habermas and the transformation of this concept reduced the foundation that Habermas intended to give to discourse, since he understood the

13 Original text in Spanish: "Sólo un terremoto nos hace cobrar conciencia de que habíamos considerado inconmovible el suelo em que estamos y nos movemos a diario. Pero incluso en tales situaciones ólo un pequeño fragmento del saber de fondo se hace incierto, queda arrancado de su inclusión en tradiciones complejas, en relaciones solidarias y en competencias individuales". 
world lived only as a foundation, being represented by the horizon of culture as an inexhaustible fund. For him, Habermas' understanding of the world lived was erroneous since the world lived represents, above all, an anticipation of meaning (STRECK, 2011, p. 113). He further understands that:

\begin{abstract}
Understood as a horizon for the (ideal) speech situations and, therefore, source and parameter for interpretations (which occur counterfactually), the lived world becomes a category suitable for the elaboration of deductive reasoning, in which there is a clear separation between the "universal" (in fact, the idea of the $U$ principle is universalizing) and the "empirical particular" (STRECK, 2011, p. 113). ${ }^{14}$ (Our translation.)
\end{abstract}

The author also points out that this is what holds Habermas' discourse to the old paradigm, for even though he has redesigned the world lived with sophisticated linguistic inks, it is still a foundation, a common sense that has counterfactual functions (STRECK, 2011, p. 94-95). Thus, the lived world constitutes a horizon and offers a disposition of cultural self-evidences, which the participants that integrate take to their interpretative tasks and which assists the consensus of all. Moreover, it also offers the solidarity of integrated groups through the values and skills of socialized individuals - representing assumptions embedded in culture (HABERMAS, 1989, p. 356).

It is therefore argued that both cultural evidence and the solidarity of integrated groups belong to the components of the world of life (HABERMAS, 1989, p. 356). Habermas' intention was to make communicative action a means by which the lived world is reproduced all together (HABERMAS, 1989, p. 356). And that is exactly what you would expect from an Organization like the UN, especially the environment in which it was forged.

In the specific case of the Security Council, as a body for the promotion and maintenance of the central objectives of the Organization as a whole, that is peace and international security, there could be no votes with different weights, especially

${ }^{14}$ In the original: "Entendido como horizonte para as situações (ideais) de fala e, portanto, fonte $e$ parâmetro para as interpretações (que ocorrem contrafactualmente), o mundo vivido transforma-se em uma categoria apta para a elaboração de raciocínios dedutivos, em que há uma nítida separação entre o 'universal'(aliás, a ideia do princípio U é universalizante) e o 'particular-empírico'". 
when the participate in meetings endowed with "personal" (national) positions and aspirations. Even if they are permitted in the light of habermasian theory, opposing positions are the means by which the best argument is reached, and coercion by one over others is not permissible for their position to be accepted. After all, it is assumed in Habermas's thesis the equal participation of all those involved - which does not exist in tlt cannot be said that the rejection of resolutions by virtue of vetoes, as exemplified by the American position in two distinct contexts, represents a consensus, since it is not an ideal/rational situation. These cases would in fact be concrete examples of unproductive communications, whose "agreements" (in this case, the rejection of a resolution) would lead to a "parallel" lived world, since interparty communication would not be ideal, the limited interaction among its members.

As a last reflection, this context (from the vote in the UN Security Council), under the habermasian prism, should be modified in order to ensure equality among its members, for the effectiveness of the Organization's objectives and for the real solidarity and to the detriment of particular (pre-molded) yearnings and the coercive practice of some. After all, if the world itself is subject to change, then why not change the Security Council itself as far as its voting system is concerned?

\section{CONCLUSION}

The theory proposed by Habermas identifies language as a means by which those involved in a discourse can influence one another in order to change their minds or conceive intentions that corroborate their purposes. In the face of this, it can be clearly said that the UN Security Council has, to a certain extent, the same objective, since its purpose is to create resolutions that have the power to guarantee international peace and security.

For Habermas, the aim of a discourse is to reach a true consensus, and for that, it supposes the existence of an "ideal situation of speech". The ideal linguistic 
situation represents an equal distribution of chances for interpretations, affirmations, etc., presupposing an equality between the speakers.

The Security Council, on the other hand, does not at any moment, nor is it close to reaching an ideal situation of speech, since it distinguishes its permanent and elected members for the counting of votes. In other words, if, for the adoption of a resolution, the Council needs nine favorable votes, including that none of the permanent members will veto the measure, this means that the decision is often in the hands of these five permanent members. Moreover, nothing seems to take national interests away from issues whose importance is - indeed - global.

The main objective of the United Nations is to guarantee peace and international security and, for this, it should aim at a greater good for all countries, not only remaining in the hands of great powers and their interests for (many) times counter-majorities. In addition, it cannot be said that these five members, in particular the United States of America, who have already decided on their final vote, participate in a meeting which presupposes an exchange of ideas and, furthermore, that there is no coercion.

Consequently, we cannot see communicative action as proposed by Habermas and the possibility that the UN can achieve its objectives, since it has members who have a pre-judgment on the subject discussed. Therefore, it is understood that at the moment the UN Security Council adopts communicative action, it will achieve a true speech and an ideal situation of speech for all members, remaining apt to reach a consensus on what is better for the international society as a whole and, therefore, what resolutions should be adopted to achieve peace and international security, which is its function as an organ of the United Nations.

\section{REFERENCES}

BATICHE, Farouk. Conselho de Segurança da ONU rejeita resolução palestina. Exame. Noticia veiculada em 31 dez. 2014 . Available at: $<$ http://exame.abril.com.br/mundo/noticias/conselho-de-seguranca-da-onu-rejeitaresolucao-palestina>. Accessed on: Jan. 21, 2015. 
BBC BRASIL. 10 perguntas para entender o conflito entre israelenses e palestinos. BBC BRASIL. Noticia veiculada em 29 set. 2014. Availalable at: <http://www.bbc.co.uk/portuguese/noticias/2014/08/140730_gaza_entenda_gf_lk>. Accessed on: Jan. 21, 2015.

. Guerra contra o Iraque 'não teria amparo legal'. BBC BRASIL. Noticia veiculada em 17 mar. 2003. Available at: <http://www.bbc.co.uk/portuguese/noticias/2003/030314_guerrailegalra.shtml>. Accessed on: Jan. 21, 2015.

BBC NEWS. History of Mid-East peace talks. BBC NEWS. Not;icia veiculada em 29 jul. 2013. Available at: <https://www.bbc.com/news/world-middle-east-11103745>. Accessed on: Jan. 26, 2018.

CARSWELL, Andrew J. Unblocking the UN Security Council: The Uniting for Peace Resolution. Journal of Conflict \& Security Law, vol. 18, n. 3, p. 453-480, 2013.

COHAN, John Alan. The Bush Doctrine and the Emerging Norm of Anticipatory SelfDefense in Customary International Law. Pace Inernational Law Review, vol. 15, n. 2, p. $283-357,2003$.

CORTELESSA, Eric. Choosing not to veto, Obama lets anti-settlement resolution pass at UN Security Council. The Times of Israel. Noticia veiculada em $23 \mathrm{dez}$. 2016. Available at: < https://www.timesofisrael.com/choosing-not-to-veto-obama-letsanti-settlement-resolution-pass-at-un-security-council/>. Accessed on: Dec. 17, 2018.

DUTRA, Delamar José Volpato. Razão e Consenso em Habermas: a teoria discursiva da verdade, da moral, do direito e da biotecnologia. Florianópolis: Ed. Da UFSC, 2005.

FOLHA ONLINE. Estados Unidos iniciam ataque ao Iraque. Folha de São Paulo. Notícia veiculada em 19 mar. 2003. Available at: <http://www1.folha.uol.com.br/folha/mundo/ult94u53179.shtml>. Acessed on: Jan. 21, 2015.

GARDNER, Richard N. Neither Bush nor the "Jurisprudes". American Journal of International Law, vol. 97, n. 3, 2003.

GRAY, Christine. The US National Security Strategy and the New "Bush Doctrine" on Preemptive Self-defense. Chinese Journal of International Law, vol. 1, n. 2, p. 437-448, 2002.

GUILHERME, Walter de Almeida. Conselho de Segurança da ONU. Justitia, São Paulo, mar./jun., 1980, p.84-97. 
HABERMAS, Jürgen. Consciência Moral e Agir Comunicativo. Rio de Janeiro: Tempo Brasileiro, 2013.

El discurso filosofico de la modernidad. Madrid: Taurus, 1989.

. Pensamento pós-metafísico: estudos filosóficos. Rio de Janeiro: Tempo Brasileiro, 1990.

Teoria de la acción comunicativa, I. Madrid: Taurus, 1987a.

. Teoria de la acción comunicativa, II. Madrid: Taurus, 1987b.

. Teoría de La Acción Comunicativa: Complementos y estúdios prévios. Catedra, 1997.

ICJ. Case Concerning Military and Paramilitary Activities in and Agaist Nicarágua: Nicarágrua x EUA. Merits - Judgment of jun. 27, 1986.

LUSA, Agência. ONU rejeita resolução que pedia a retirada de Israel de territórios palestinos. Agência Brasil. Noticia veiculada em 30 dez. 2014. Available at: $<$ http://agenciabrasil.ebc.com.br/internacional/noticia/2014-12/onu-nao-aprovaresolucao-pedindo-retirada-de-israel-de-territorios>. Acessed on: Jan. 21, 2015.

LUZ, Taciano. Estados-Membros. Info ONU. News disclosed on Nov. 13, 2012. . Available at: : <https://infoonu.wordpress.com/2012/11/13/estados-membros/>. Acessed on: Jan. 19, 2015.

MATILAL, Bimal Krishna. Logic, language and reality: Indian philosophy and contemporary issues. Motilal Banarsidass Publishers Private Limited, 2008.

MAZZUOLI, Valerio de Oliveira. Curso de Direito Internacional Público. São Paulo: Editora Revista dos Tribunais, 2011.

MCGREAL, Chris. UN vote on Palestinian state put off amid lack of support. The Guardian. News disclosed on Nov. 11, 2011. Available at: $<$ https://www.theguardian.com/world/2011/nov/11/united-nations-delays-palestinianstatehood-vote >. Accessed on: Jan. 15, 2018.

NYT. Mr. Clinton's Mideast Peace Plan. New York Times. News disclosed on Dec. 27, 2000. Available at: <https://www.nytimes.com/2000/12/27/opinion/mr-clinton-smideast-peace-plan.html>. Accessed on: Jan. 16, 2018.

OLIVEIRA, Manfredo Araújo de. Reviravolta Linguístico-pragmática na Filosofia Contemporânea. São Paulo: Loyola, 2001. 
PILKINGTON, Ed. US vetoes UN condemnation of Israeli settlements. The Guardian. News disclosed on Feb. 19, 2011. Avilable at: $<$ https://www.theguardian.com/world/2011/feb/19/us-veto-israel-settlement>. Accessed on: Jan. 14, 2018.

PORTELA, Paulo Henrique Gonçalves. Direito Internacional Público e Privado, incluindo noções de direitos humanos e de direito comunitário. 4 ed. rev. ampl. e atual. Salvador: Editora Jus Podivm, 2012.

RAMONET, Ignacio. A era da guerra perpétua. Le Monde Diplomatique Brasil. News disclosed on Jan. 1, 2003. Available at: <http://www.diplomatique.org.br/acervo.php?id=880>. Acessed on: Jan. 21, 2015.

RUDOREN, Jodi. What the Oslo Accords Accomplished. New Tork Times. News disclosed on Sept. 30, 2015. Available at: $<$ https://www.nytimes.com/2015/10/01/world/middleeast/palestinians-mahmoudabbas-oslo-peace-accords.html>. Accessed on: Jan. 17, 2018.

SACONI, Rose; ENTINI, Carlos Eduardo. Com justificativa falsa, Iraque era invadido há 10 anos. Acervo Estadão. News disclosed on Mar. 19, 2013. Available at: $<$ http://acervo.estadao.com.br/noticias/acervo,com-justificativa-falsa-iraque-erainvadido-ha-10-anos,8951,0.htm>. Acessed on: Jan. 21, 2015.

SCHWEIGMAN, David. The Authority of the Security Council Under Chapter VII of the UN Charter. The Hague: Kluwer Law International, 2001.

SITO, Santiago Artur Berger. Entre os discursos de fundamentação e os discursos de aplicação no direito: da cisão à applicatio - um olhar a partir da crítica hermenêutica do direito. 2012. 171 f. Dissertação (Mestrado em Direito Público) - Programa de Pós Graduação em Direito, Universidade do Vale do Rio dos Sinos (UNISINOS), São Leopoldo, 2012.

STRECK, Lenio Luiz. Verdade e Consenso: constituição, hermenêutica e teorias discursivas. São Paulo: Saraiva, 2011.

UN. Carta das Nações Unidas, 1945. Available at: $<$ http://unicrio.org.br/img/CartadaONU_Versolnternet.pdf>. Acessed on: Jan. 19, 2015.

Resolução $1991 \quad \boldsymbol{A}$ (XVIII). 1963. Available at: <http://www.un.org/en/sc/repertoire/otherdocs/GAres1991.pdf>. Acessed on: Jan. 19, 2015.

Resolution $1441 \quad$ (2002). Available at: $\overline{<h t t p: / / w w w . u n . o r g / D e p t s / u n m o v i c / d o c u m e n t s / 1441 . p d f>. ~ A c e s s e d ~ o n: ~ J a n . ~ 21, ~}$ 2015. 
. Resolution 181(II): Future government of Palestine. [A/RES/181(II) - 29 1947]

Available at: <https://unispal.un.org/DPA/DPR/unispal.nsf/0/7F0AF2BD897689B785256C3300 61D253>. Accessed on: jan. 16, 2018.

Resolution 242 (1967): 22 nov. 1967. Available on: <www.un.org/Depts/dpi/palestine/ch3.pdf>. Accessed on: Jan. 15, 2018.

Resolution 338 (1973): 22 out. 1973. Available on: <www.un.org/Depts/dpi/palestine/ch3.pdf>. Accessed on: Jan. 15, 2018.

UNMIMC. UNMOVIC: Basic Facts. s/d. Available at: <http://www.unmovic.org/>. Acessed on:Jan. 21, 2015.

ZANELLA, Diego Carlos. Filosofia e Sociedade: uma leitura a partir de Habermas. Fragmentos de Cultura, v. 19, n. 9/10. Goiânia, 2009. p. 699-709. 